\title{
COVID and the Common Good
}

\section{Greg Latemore ${ }^{1}$ (1)}

Received: 22 July 2020 / Accepted: 3 November 2020/ Published online: 9 November 2020

(C) Springer Nature Switzerland AG 2020

\begin{abstract}
This article examines the nature of individual goods, public goods, and the common good in the context of the Coronavirus Disease 2019 (COVID). 'Common' in 'common good' is what applies to all persons without exception, and 'good' is what contributes to human flourishing. The common good is regarded as the communion of persons in good living. Addressing the relationship between the economy and society, it is proposed that the marketplace subsists within society. Acknowledging that we are deeply connected, the article employs the philosophies of MacIntyre, Maritain and Sandel to highlight the importance of reciprocity, relationships, and generosity as characteristics of the common good. Two narratives in the public discourse are observed in these COVID days - one characterised by fear and selfishness, the other by hope and generosity. The author recognises that this pandemic can be conceived as a 'wicked' problem in a 'volatile, uncertain, complex, and ambiguous' world, and implications for leaders and citizens in managing COVID are suggested.
\end{abstract}

Keywords Common good $\cdot$ Community $\cdot$ COVID $\cdot$ Human flourishing $\cdot$ Goods

\section{Introduction}

The Master sat in rapt attention as the renowned economist explained the blueprint for development. 'Should growth be the only consideration in an economic theory?' he asked. 'Yes. All growth is good in itself.' 'Isn't that the thinking of the cancer cell?' replied the Master (de Mello 1987: 80).

This opening story highlights that growth for its own sake is not necessarily a good thing: after all, the Coronavirus Disease 2019 (COVID-19) - hereafter 'COVID' - is a virus that merely seeks to replicate itself and spread. This article begins by recognising that we are deeply connected, and addresses the relationship between the economy and society. In the context of COVID, the nature of the common good is then considered through the lenses of three

Greg Latemore

gregory.latemore1@my.nd.edu.au; greglatemore@gmail.com

1 The University of Notre Dame Australia (School of Business), Broadway, NSW, Australia 
philosophies, those of MacIntyre, Maritain and Sandel. The article concludes by offering some suggestions for leaders and citizens in managing this pandemic through the paradigm of the common good.

\section{COVID Reminds us that we are Deeply Connected}

COVID has reinforced that we are globally connected, both for ill and for good as a human species. According to the World Health Organization dashboard (WHO 2020a), this virus has already infected over 14 million people, with more than 600,000 deaths, and it has spread to every country except Antarctica. Just as COVID knows no borders and respects no boundaries, the human community is inexorably linked now in ways that were not possible during the so-called Spanish Flu (1918 - 1920) which killed an estimated 20 - 50 million victims, nor during the Black Death (1347-1352) which killed an estimated 25-30 million people (Cartwright 2020).

As the Irish proverb asserts, Ar scáth a chéile a mhaireann na daoine, 'in the shadow of each other, we live', meaning that we are shielded from the sun by others, the phrase evoking a sense of interdependence (Carswell 2015). The African concept of ubuntu goes even deeper'I am because we are' (Gade 2012), meaning that our human development depends upon the prior presence and support of the community (Obioha 2014a, b). Our very existence is contingent upon our membership of the human community: we both depend upon and are impacted by what happens elsewhere. COVID has entered a globalised world that is both interconnected and interdependent in trade, finance, communications, culture, and public health (Jones 2013; Makhlouf 2017).

While it is a truism that we are all part of the human community, various writers have nonetheless critiqued the common mantra that 'We are all in this together' as being an inaccurate commentary on the experience of those who are most affected by COVID (Guarnieri 2020; Hornery 2020). After all, the wealthy and those who are able to 'socially-distance' are being less impacted by the spread of the virus, while lower-income people are at greater risk. This was also evidently the case during the Spanish flu when the poor, and those who were living in close household and community proximity, suffered the most (Bowleg 2020; Pambuccian 2020).

\section{The Context of COVID: The Economy and Society}

According to the French philosopher, Jacques Maritain (1882-1973), the economy exists to meet the needs of the people rather than people existing to service the needs of the State (Maritain 1960,1998). Society and the marketplace are not two mutually-exclusive entities the marketplace subsists within society. Society does not exist to serve the State (Maritain 1960, 1998), rather, the State is part of the body politic (Bainton 1952), and its role is to ensure that society is the beneficiary of the contributions of its own citizens (McInerny 2007).

A trade-off between health policy and economic goals has become evident during COVID: the USA under President Trump has been more concerned with encouraging and supporting Americans back to work rather than dealing directly with the serious negative effects of this pandemic; other nations such as New Zealand and Australia have been more cautious about opening State and Territory borders to 're-boot' the economy. Public health and the economy are being regarded as competing imperatives by political leaders. Friedman (2020) refers to this significant dilemma as the 'hellish trade-off between medical health and economic health'. 
Various commentators in recent times (Anthony 2020; Hague 2019; Sandel 2018) have highlighted the legacy of a globalised world in a highly-privatised and individualised society such as in the USA where the poor are significantly disadvantaged in access to health care and paid sick leave, and in dealing with the disastrous effects of the coronavirus. It has also been postulated that Western free-market capitalism has lost sight of the common good in favour of 'market triumphalism' where there is no equality and little social justice (Glunt 2020).

Instead, and in light of COVID, representatives of some 17 countries are already proposing new ways to foster a prosperous global economy by recognising economic equality, and by putting people's needs and democratic values first: from a 'Common Good Product', which could sit above the 'Gross Domestic Product', to investments in sustainable food production and health; from 'Ethical World Trade' to a financial transaction tax to 'Common Good Balance Sheets' for businesses. This movement, calling itself the Economy for the Common Good, regards the current COVID crisis as the opportunity to master the transition from the prevailing economic model - which contributes to climate change, loss of biodiversity and inequality - towards a better future (ECG 2020).

A tension is currently evident across the world between the pursuit of individual liberty and respecting the common good. For example, in the USA, President Trump is insistent that wearing masks during COVID is a matter of personal choice and individual freedom, while others - especially health officials and COVID response coordinators - are mandating the wearing of masks to protect the community as a matter of public policy (Cathey 2020). It is evident in the USA that advocating and wearing masks has also become politicised as a symbol of support for Democratic policies since the Presidential candidate, Joe Biden, typically wears one. This tension between liberty and the common good is also evident between those who decide to participate in the Black Lives Matter protests to express their personal views against racism, and those who decide to refrain from protesting during the pandemic - even if they agree with the motivation to participate - in order to protect the community from transmission of the virus.

Indeed, there has long been a social and political struggle, especially in America, between protecting personal liberty and nurturing a civil society (Woodard 2016), a struggle between 'me and we' (Anthony 2020). This represents a choice between two competing 'goods'. The nature of various goods will now be considered.

\section{The Nature of 'Goods' and the Common Good}

\section{Individual Goods}

The Scottish philosopher, Alasdair MacIntyre (2016) points out that the common good is not to be confused with the idea, often encountered in economics, of public goods. These are also to be contrasted with an 'individual good' which is what one can both achieve and enjoy as an individual, such as a glass of whisky or a plate of fish and chips. One could add cars and parking spaces as examples of individual or private goods.

\section{Public Goods}

'Public goods' are those which can be enjoyed as an individual, but only through mutual cooperation, such as being a member of a choir (see Stevenson 2020). MacIntyre (2016) 
observes that public goods include roads, banks, and schools and are enjoyed as members of a community (MacIntyre 2016: 168 - 169). Other public goods which might also be identified include lighthouses, freeways, sewerage systems, and street lighting.

Economists further distinguish between private goods, common goods, club goods and public goods against two criteria, excludability and rivalry. The first criterion, excludability, refers to whether other people can be prevented from using the good. Rivalry refers to whether a good has a rival in consumption: that is, whether one person's use of the good necessarily reduces another person's capacity to use it. Private goods are excludable and rival. Examples of private goods include food and clothes. Common goods are non-excludable and rival. A classic example of a common good is fish-stocks within international waters. Club goods are excludable but non-rival. Cable television and cinemas are examples of club goods. Public goods are non-excludable and non-rival. Public goods include public parks, national defence, and the air which we breathe (see Cornes and Sandler 1996; Hess and Ostrom 2007; Weimer and Vining 2017).

MacIntyre illustrates his conception of public goods by discussing the form they take when sought cooperatively in families, schools, and workplaces. These are social organisations that flourish by fostering the development of children, students, and workers. Teachers, for example, 'achieve their good qua teachers and contribute to [the] common good by making the good of their students their overriding good' (MacIntyre 2016: 172-173). The good of students, he adds, does not consist only or mainly in the mastery of economically valuable skills but in having 'a sense of the ends that should be theirs as contrasted with the ends that others for their own purposes impose on them' (MacIntyre 2016: 173). Similarly, he proposes that workplaces ought to be organised around the provision of excellent products and services, achieved through shared deliberation among workers. Market forces and governments subservient to capital are, MacIntyre highlights, powerful impediments to the existence of schools and workplaces in which individuals flourish.

It is worth observing with Kraut (2018) that MacIntyre's notion of communal flourishing is not an additional goal beyond the flourishing of the individuals who belong to a community. Families, for example, should desire the flourishing of each of their members; what it is for a family fully to flourish is simply for each of its members to achieve the goods that are specific to family life. Joint activities in families, schools, and workplaces, in which no one can engage as a solitary individual, still enable individuals to flourish within them.

\section{The Common Good}

'Common' in 'common good' is what applies to all persons without exception, and 'good' is what contributes to human flourishing (Mea and Sims 2018). Maritain simply refers to the common good as 'the communion of persons in good living' (Maritain 1966: 51). The common good for Maritain is an aspect of integral humanism, which is a social philosophy respecting human dignity and is oriented towards the ideal of a fraternal community. It is directed towards a better life for the brotherhood of man [sic] and the concrete good of the community (after Maritain 1996: 155). This moral philosophy of human freedom underpinned the UN Declaration of Human Rights (United Nations 1948) which Maritain was involved in promoting, and indirectly, in drafting (Sweet 2019).

The common good is to be distinguished from 'common goods', the former concept referring, not to objects such as fish-stocks, but to a condition. The common good also embodies the notion and the principle of 'the highest good' - summum bonum - one which is shared and beneficial for 
all (or most) members of a given community (Rashdall 2005), and which, in Kantianism, was used to describe the ultimate importance, the singular and overriding purpose which human beings ought to pursue (Federica 2016; Rohlf 2020).

The common good has been defined as 'a set of conditions which enables the members of a community to attain for themselves reasonable objectives, or to realise for themselves the value(s) for the sake of which they have reason to collaborate with each other (positively and/ or negatively) in a community' (Finnis 1999: 155). O'Brien (2008) further elaborates that the common good is both a condition for, and the result of, the happiness which those persons who participate in the common good attain by living virtuously, that is in the promotion of virtuousness. For Maritain, the common good is 'the end of the social whole' (Maritain 1966: 49) and 'the true ends of human persons' (Maritain 1966: 48).

According to Mea and Sims (2018) and Melé (2016), a strength of Maritain's view of the common good is that it can be recognised as a core principle in dignity-centred ethics, a principle promoting conditions which enhance the opportunity for the human flourishing of all people within a community.

Maritain's view of society is one characterised by a liberty of expansion, that is, 'freedom in terms of virtue' (Hittinger 2002: 82) where the fruits of citizens' efforts 'flow back' to them as persons in a fraternal community (Maritain 1966: 55). Those who do the work of organisations, and who contribute to economic prosperity, are citizens first of all, and Maritain would advocate that citizens' efforts should benefit them and should flow back to them since '[t]he common good of the city is neither the mere collection of private goods nor the proper good of a whole-like the hive' (Maritain 1966: 50-51). Reciprocity and mutuality are therefore key aspects of the common good: each citizen contributes to the common good and the common good benefits citizens in return. The common good transcends both private (individual) goods as well as public (collective) goods.

While approaches to justice have included maximising utility as advocated in the eighteenth century by Jeremy Bentham (2007) and respecting freedom of choice as advocated in the twentieth century by John Rawls (1999), it has been argued in the twenty-first century by the American philosopher, Michael Sandel that there are limits to both such alternatives -

A just society cannot be achieved simply by maximising utility or securing freedom of choice. To achieve a just society we have to reason together about the meaning of the good life, and to create a public culture hospitable to the disagreements that will inevitably arise (Sandel 2009: 261).

As MacIntyre (2016) similarly notes, our pursuit of the common good requires a willingness to listen to and account for differences of perspective. A more robust public engagement with such disagreements could well provide a stronger, not a weaker, basis for mutual respect, as Sandel further proposes (2009: 268). The common good requires that we see things the way our neighbours and opponents do, converse respectfully, and reason together toward finding common solutions to complex problems.

Accordingly, a community's agreeing to be vaccinated is an illustration of communal and cooperative behaviour which is based upon collective reasoning and a respectful openness to different views, thereby reflecting and reinforcing the common good. The many crowdfunding ventures established to support people in need, especially during natural disasters such as floods, droughts, and bushfires, and during human-initiated community emergencies such as COVID, also bear testimony to the benefits of cooperative behaviour by finding and funding solutions to complex problems. 


\section{The Public Interest}

The principle of 'the public interest' reflects a communal ideal in civic life where 'burdens are shared and resources are pooled' (Hussain 2018). The meaning of the term, or the approach indicated by the use of the term especially in the public service, is to direct consideration and action away from private, personal, parochial, or partisan interests towards matters of broader, public concern (PSC 2020). Acting in the public interest typically has two separate components: firstly, objectives and outcomes - that the objectives and outcomes of the decisionmaking process are in the public interest, and secondly, process and procedure - that the process adopted and procedures followed by decision-makers in exercising their discretionary powers are in the public interest (Wheeler 2006). Dealing effectively with COVID has reinforced the importance of acting in the public interest where decisions have been taken to benefit global and local communities, not to preserve individual interests, or even individual freedoms. Enforcing border restrictions and mandating quarantine measures as part of a COVID suppression strategy are not merely legal impositions, but are expressions of actions taken in the public interest.

Recent reflections upon the principles of a democracy also highlight that the public interest of all the people should be at its heart, not a particular interest group, class, or faction. As Grayling observes (2020: 165), '[a] democratic government is neither majoritarian nor minoritarian, but inclusive in its aims, duties and purposes'. Further, those who serve in the parliament should also demonstrate selflessness, integrity, objectivity, accountability, openness and honesty as their general principles of conduct (Grayling 2020: 206-207). In similar vein, MacIntyre endorses the need for a practical ethics which is grounded on virtuousness not viciousness, where a virtue is an acquired human quality which demonstrates excellence in human agency (MacIntyre 2007; see Hursthouse and Pettigrove 2018).

Such principles of right conduct in a parliamentary democracy, and the principle of the public interest, echo the views of Maritain who believed that the hallmark of a civilization itself was found in 'radical generosity' towards others (Maritain 1966: 48). For Maritain (1966), the individual is the lower self, the lower good of the human being while the person can be defined as an expression of the higher self, the higher good of the human being. Maritain contrasts individuality (the material component) with personality (the spiritual component) and highlights that the individual is but a narrow expression of the ego - 'to grasp for itself' - while personality is an expression of the self - 'giving itself' (Maritain (1966: 37, 39). Maritain believed that we were at our best when we were active citizens and contributing members of a community. To become fully a person is to be in relationship with others. To act in the public interest is to foster the pursuit of the common good.

\section{Managing COVID as Managers and as Leaders}

It is acknowledged that there are different ways in which management can be understood, such as risk management, anger management, and management of an organisation. Management can be broadly defined as the process of providing order and consistency to organisations (Kotter 1990) with four functions traditionally identified - planning, organising, staffing, and controlling (Fayol 2013). The domains of management typically include self-management, team management and organisational management, as addressed in the academic discipline of organisational behaviour. 
This global pandemic could well be regarded as a 'wicked problem' to be managed 'wicked' referring to the fact that it is not 'tame', but complex, open-ended, and intractable (Head 2008). The term 'wicked' in this context is used, not in the sense of being evil, but rather as an issue highly resistant to resolution (Briggs 2007). Similarly, other scholars have addressed the challenge of managing in a VUCA world - that is, a world which is volatile, uncertain, complex, and ambiguous (Thurman 1991). In the face of this, it has been suggested that agile leaders need to be 'flexible, fast, and focussed' (Horney et al. 2010). Similarly, Bennett and Lemoine (2014) encourage leaders to build resource capacity, to build in 'slack', to experiment, and to invest and share information widely.

Modern social problems such as indigenous disadvantage, poverty, obesity, and climate change are seen as ill-defined, interlinked, and relying on political judgments rather than scientific certitudes. In this sense, most major public policy problems are not 'tame' but 'wicked' (Rittel and Webber 1973: 160) - they are inherently resistant to a clear statement of the problem, and resistant to a clear and agreed solution. It is to be hoped that, while a vaccine might be discovered to 'tame' COVID, managing its impact will still present a wicked problem for healthcare professionals and political leaders for some time. Effective solutions to such wicked problems in the context of internal security and welfare administration appear to be achieved by commitment, communication, and co-ordination (Lagreid and Rykkja 2015).

The lessons already being learned from the perspective of crisis management about COVID have employed the four 'levers' from the World Health Organization: readiness, preparedness, implementation, and minimisation of the impact post-COVID (WHO 2020b). It is evident that countries have varied in their readiness and response to this global pandemic, due to factors such as the prevalence of healthcare resources, and other factors based upon socio-cultural norms. Japan already exhibits a culture of wearing masks, and this has even become a fashion statement with ready compliance on wearing masks during COVID being evident among many Asian countries as soon as this pandemic was declared (see Aslam and Hussain 2020). Further, it is apparent for example, that the leaders of Brazil and Nicaragua adopted a 'handsoff' approach from the outset; Germany and New Zealand responded with science, and a 'hands-on' approach; while the USA's approach was both mixed and confusing (Blackburn and Ruyle 2020).

Dealing with previous public emergencies such as Hurricane Katrina in New Orleans in 2005 was traditionally by disaster and crisis management (John 2009; Tanguay-Renaud 2009; Zack 2009). It is now suggested that an alternate route of inquiry which could be undertaken towards COVID is through existentialist philosophy (Vandekerckhove 2020). As has been shown, this article has also taken a philosophical approach which has been focussed upon the notion of the common good by employing the philosophies of Maritain, MacIntyre and Sandel.

Scholars have long distinguished management from leadership (Bennis and Nanus 1985; Rost 1991; Zaleznik 1977) with leadership being defined as a process whereby an individual influences a group to achieve a common goal (after Northouse 2018). Certain leadership behaviours have been regarded as being more significant than others in fostering results among followers including authentic, servant, and transformational leadership styles (Latemore 2020b; Yukl and Gardner III 2020).

During COVID, crisis healthcare leadership employing effective and ethical communication which builds trust (Häyry 2020a, 2020b) has become vitally important. Leaders who are clear, honest, and compassionate are perceived to be authentic (Latemore 2020c), where authentic leadership is regarded as a positive psychological capacity possessing three characteristics - an intrapersonal perspective which focuses on the leader's self-awareness; an interpersonal 
perspective characterised by genuine relationships with followers; and a development perspective where the leader develops over time, especially when such growth is triggered by life events (Northouse 2018). The contrast between some political leaders and the extent to which they are seen to be credible and authentic or not in managing COVID is being observed (Latemore 2020c), and others are considering whether the leader's gender and the accompanying behaviour impacts upon how successful leaders are in managing COVID (Henley and Aingel Roy 2020).

While the lessons for leaders during COVID are yet to be fully appreciated, scholars have already identified the importance of what is being termed 'identity leadership', that is, leaders need to represent us, and in a crisis, 'us' becomes more inclusive, that leaders need to craft and embed a sense of 'us', and that this creates a platform for citizenship (Haslam 2020; Letten et al. 2020). To that extent, it seems effective political leadership in the face of COVID has involved more than taking responsive action to the crisis but includes the ability to constitute meaning for their citizens during this crisis (Blok 2020).

\section{Managing COVID as Citizens}

An old Cherokee chief was teaching his grandson about life. 'A fight is going on inside me,' he said to the boy. 'It is a terrible fight and it is between two wolves. One is evil - he is anger, envy, sorrow, regret, greed, arrogance, self-pity, guilt, resentment, inferiority, lies, false pride, superiority, self-doubt, and ego. The other is good - he is joy, peace, love, hope, serenity, humility, kindness, benevolence, empathy, generosity, truth, compassion, and faith. This same fight is going on inside you and inside every other person too.' The grandson thought about it for a minute and then asked his grandfather, 'which wolf will win?' The old chief simply replied, 'the one you feed.' (Cherokee nd).

Similarly, two parallel narratives in the public discourse seem to be occurring during COVID days - one based upon fear and selfishness, the other based upon hope and generosity. The best and worst manifestations of human nature have been on show during this global health crisis, ranging from fear, scepticism, and individualism, to serenity, trust, and community awareness (Latemore 2020a).

On the one hand, we have witnessed acts of fear. For example, it has been reported that the sale of firearms and ammunition in the USA have increased by $85 \%$ in March 2020 and $71 \%$ in April 2020, the highest levels ever recorded in the USA (Morral and Travis 2020). On the other hand, we have seen acts of generosity, including a significant increase in donations during COVID (Bibby 2020), and the 'pandemic kindness movement' which has been created by Australian clinicians 'to provide health workers with easy access to curated resources' (PK 2020). Similarly, a web search on 'generosity during COVID-19' revealed 54,800,000 results, while a search on 'selfishness during COVID-19' produced 39,100,000 results, perhaps bearing testimony that generosity is outweighing selfishness during these COVID times.

Downloading the 'COVID safe' app, observing social distancing, practicing personal hygiene with regular sanitisation, undergoing COVID testing, and wearing of masks in public, are all expressions of a community consciousness in pursuit of the common good, and not just a reflection of personal desires to avoid becoming infected.

To foster the common good, generosity of spirit is essential which has been evident throughout the coronavirus pandemic, notwithstanding that selfish behaviour in panicbuying and hoarding of certain consumer items have also been witnessed. Research has shown that lack of control, intolerance of uncertainty, and distress intolerance are predictors of 
hoarding behaviour. Where individuals also experience anxiety, they are more likely to start stockpiling (Notebaert 2020). Rather, community well-being is protected and fostered by observing public health measures and engaging in co-operative behaviour.

The enduring testimony of these times is the selflessness and dedication of whole communities, and especially from frontline healthcare workers who have earned the admiration of all citizens in helping us deal with COVID (Brooks and Morris 2020). Fatalism and despair have been balanced by generosity and hope for a better world. The community indeed benefits from such generosity and is itself nourished by it - as Maritain writes, a 'liberty of expansion' occurs when the common good is respected. Such liberation is expansive because it leads to a 'love of others' and 'the communication of generosity (Maritain 1966: 51). Maritain conceives of liberty of expansion as 'the flowering of moral and rational life' (Hittinger 2002: 82).

\section{Conclusion}

In the midst of widespread death and human misery, a different form of prosperity is being discovered during this pandemic. Eudaimonia - usually translated as 'human flourishing' (Arjoon et al. 2018) - is the outcome of recognising the public interest and working towards the common good. A renewed appreciation of the benefits of family life and community have been widely reported during these COVID times. This article presented the view that community well-being is central to society and that the economy serves the community - not vice versa. Various philosophies regarding the common good have been harnessed to address and support this argument. The common good might well be considered as the source and summit of human wellbeing, and is characterised and fostered by reciprocity, relationships, and generosity.

The loss of life, hardship, suffering, and unemployment throughout the world which is still occurring during COVID have been unprecedented and tragic in modern times. While it is anticipated that there will be more fear, selfishness, polarised politics, and international friction post-COVID (Wolf 2020), it is to be hoped that the generosity of community spirit, fostering the common good, which has also been evident during this pandemic might be sustained for our ongoing well-being. The implications for management and leadership in a post-COVID world will continue to be significant.

Data Availability Not applicable.

\section{Compliance with Ethical Standards}

Conflict of Interest Not applicable.

Code Availability Not applicable.

\section{References}

Anthony, T. 2020. Me and we: Individual rights, common good and coronavirus. US News. Retrieved on 23rd June 2020 from https:/www.usnews.com/news/politics/articles/2020-05-18/me-and-we-individual-rightscommon-good-and-coronavirus 
Arjoon, S., A. Turriago-Hoyos, and U. Thoene. 2018. Virtuousness and the common good as a conceptual framework for harmonizing the goals of the individual, organizations, and the economy. Journal of Business Ethics 147 (1): 143-163.

Aslam, H., and Hussain, R. 2020. Fighting COVID-19: Lessons from China, South Korea and Japan. Islamabad: Pakistan. Sustainable Development Policy. Retrieved on 3rd July 2020 from https://www-jstor-org. ezproxy1.acu.edu.au/stable/resrep24381

Bainton, R.H. 1952. Maritain's 'man and the state' [Book review]. Political Science Quarterly 67 (1): 127-129.

Bennett, N., and Lemoine, G. J. 2014. What VUCA really means for you. Harvard Business Review [Jan-Feb], 92(1,2), 27-31.

Bennis, W., and B. Nanus. 1985. Leaders: The strategies for takingcharge. New York, NY: Harper \& Row.

Bentham, J. 2007. Introduction to the principles of morals and legislation. Paperback ed. New York: Dover Publications (Original work published 1789).

Bibby, P. 2020. Generosity flows amidst the COVID crisis. Echo Net Daily. May 6th 2020. Retrieved on 2nd July 2020 from https://www.echo.net.au/2020/05/generosity-flows-amidst-the-covid-crisis/

Blackburn, C. D., and Ruyle, L. 2020. How leadership in various countries has affected COVID-19 response effectiveness. The Conversation. 27th May 2020. Retrieved on 29th May 2020 from https://theconversation. com/how-leadership-in-various-countries-has-affected-covid-19-response-effectiveness-138692

Blok, V. 2020. What is (business) management? Laying the ground for a philosophy of management. Philosophy of Management 19: 173-189.

Bowleg, L. 2020 [online June] We're not all in this together: On COVID-19, intersectionality, and structural inequality. American Journal of Public Health, 110(7). DOI: https://doi.org/10.2105/AJPH.2020.305766.

Briggs, L. 2007. Tacking wicked problems: A public policy perspective. Canberra, ACT: Australian Public Service Commission. [Archived]. Retrieved on 3rd July 2020 from https://www.apsc.gov.au/tacklingwicked-problems-public-policy-perspective

Brooks, L., and Morris, S. 2020. Millions of Britons clap for carers on coronavirus frontline. The Guardian. Retrieved on 21st July 2020 from https://www.theguardian.com/world/2020/mar/26/millions-of-britonsclap-for-carers-on-coronavirus-frontline

Carswell, S. 2015. 'In the shadow of each other, we live', President says at Berkeley. Irish Times. Retrieved on 28th June 2020 from https://www.irishtimes.com/news/ireland/irish-news/in-the-shadow-of-each-other-welive-president-says-at-berkeley-1.2409339

Cartwright, M. 2020. Black Death. Ancient History Encyclopedia. Retrieved on 22nd June 2020 from https://www.ancient.eu/Black_Death/

Cathey, L. 2020. Despite new mandatory mask rules, trump insists it's everyone's 'personal choice'. $A B C$ News. Retrieved on 21st July 2020 from https://abcnews.go.com/Politics/mandatory-mask-rulestrump-insistspersonal-choice/story?id=71519019

Cherokee, nd. Cherokee parable. [Unconfirmed]. Pearls of Wisdom: Awakening Personal and Global Consciousness. Retrieved on 2nd July 2020 from http:/www.sapphyr.net/natam/two-wolves.htm

Cornes, R.T., and Sandler. 1996. The theory of externalities, public goods, and club goods. 2nd ed. Cambridge: Cambridge University Press (Original work published 1986).

de Mello, A. 1987. One Minute Wisdom. Anand: Gujarat Sahitya Prakash.

ECG [Economy for the Common Good]. 2020. Towards a post-COVID economy for the common good. Retrieved on 21st July 2020 from https:/www.ecogood.org/towards-a-post-covid-economy-for-thecommon-good/

Fayol, H. 2013. General and Industrial Management. Martino publishing (original work published in French 1916).

Federica, F. 2016. The highest good and the notion of the good as object of pure practical reason. In The highest good in Kant's philosophy, ed. T. Höwing, 17-32. Berlin, DE: De Gruyter Press.

Finnis, J. 1999. Natural law and natural rights. Oxford: Clarendon Press.

Friedman, T. L. 2020. Finding the 'common good' in a pandemic. The New York Times [opinion]. Retrieved on 29th June 2020 from https://www.nytimes.com/2020/03/24/opinion/covid-ethics-politics.html

Gade, C.B. 2012. What is "ubuntu?" Different interpretations among South Africans of African descent. South African Journal of Philosophy 31 (3): 484-503.

Glunt, N. 2020. Sandel: Equality is the key to the common good. The Chautauquan Daily. 8th July 2011. Retrieved on 29th June 2020 from https:/chqdaily.wordpress.com/2011/07/08/sandel-equality-is-the-key-tothe-common-good/

Grayling, A.C. 2020. The good state: On the principles of democracy. London: OneWorld Publications.

Guarnieri, M. 2020. Stop saying 'we are all in this together'. You have money. It's not the same. The Washington Post. Retrieved on 21 st July 2020 from https:/www.washingtonpost.com/outlook/2020/04/18/coronavirusretail-jobs-inequality/ 
Hague, U. 2019. How our economy made it impossible for an average person to live a decent life. Eudaimonia \& Co within Heterodox Economists. Retrieved on 23rd June 2020 from https://heterodox.economicblogs. org/mike-norman-economics/2019/norman-umar-hague-economy-life

Haslam, S. A. 2020. Leadership. In Jetten, J., Reicher, S. D., Haslam, S. A., \& Cruwys, T. (2020). Together Apart: The Psychology of COVID-19 (pp. 34 40). ebook. Retrieved on 1st June 2020 from https://www. socialsciencespace.com/wp-content/uploads/Together-Apart-Complete-ms.pdf

Häyry, M. 2020a. The COVID-19 pandemic: A month of bioethics in Finland. Cambridge Quarterly of Healthcare Ethics. 30th April, 1-9. https://doi.org/10.1017/s0963180120000432.

Häyry, M. 2020b. The COVID-19 pandemic: Healthcare crisis leadership as ethics communication. Cambridge Quarterly of Healthcare Ethics. 20th May, 1-14. https://doi.org/10.1017/S0963180120000444.

Head, B. 2008. Wicked problems in public policy. Public Policy 3 (2): 101-118.

Henley, J., and Aingel Roy, E. 2020. Are female leaders more successful at managing the coronavirus crisis? The Guardian [25th April 2020]. Retrieved on 4th July from 2020 https://www.theguardian.com/world/2020 /apr/25/why-do-female-leaders-seem-to-be-more-successful-at-managing-the-coronavirus-crisis

Hess, C., and E. Ostrom. 2007. Understanding knowledge as a commons: From theory to practice. Cambridge: The MIT Press.

Hittinger, J. 2002. Three philosophies of human rights - Locke, Richards and Maritain. Liberty, Wisdom and Grace: Thomism and Democratic Political Theory. Lanham, MD: Lexington Books. (pp. 73-86).

Hornery, A. 2020. No, we're not all in this together. The Sydney Morning Herald. Retrieved on 21st July 2020 from https://www.smh.com.au/culture/celebrity/no-we-re-not-all-in-this-together-20200505-p54q0p.html

Horney, N., B. Pasmore, and T. O’Shea. 2010. Leadership agility: A business imperative for a VUCA world. People and Strategy 33 (4): 32-38.

Hursthouse, R., and Pettigrove, G. 2018. Virtue ethics. The Stanford Encyclopedia of Philosophy (Winter 2018 edition). Zalta, E. N. (Ed.), retrieved on 27th June 2020 from https://plato.stanford.edu/archives/win2018 /entries/ethics-virtue

Hussain, W. 2018. The common good. The Stanford Encyclopedia of Philosophy (Spring 2018 edition), Zalta, E. N. (Ed.). Retrieved on 29th June 2020 from https://plato.stanford.edu/archives/spr2018/entries/commongood/

John, S.D. 2009. Supreme emergencies, epistemic murkiness and epistemic transparency. Philosophy of Management 8: 3-12.

Jones, R.J.B. 2013. Globalisation and interdependence in the international political economy. London: Bloomsbury Publishing.

Kotter, J. 1990. A force for change: How leadership differs from management. New York: Free Press.

Kraut, R. 2018. Review of Alasdair MacIntyre's 'ethics in the conflicts of morality'. Notre Dame Philosophical Reviews: An Electronic Journal. Retrieved on 25th June 2020 from https://ndpr.nd.edu/news/ethics-in-theconflicts-of-modernity-an-essay-on-desire-practical-reasoning-and-narrative/

Lagreid, P., and L.H. Rykkja. 2015. Organizing for 'wicked problems' - analyzing coordination arrangements in two policy areas. International Journal of Public Sector Management 28 (6): 475-493.

Latemore, G. 2020a. Human responses to COVID-19. New Philosopher [Virus views]. Posted 23rd March 2020. Retrieved on 24th June 2020 from https:/www.newphilosopher.com/articles/virus-views-human-responses/

Latemore, G. 2020b. From valuable resource to valued person: Ontologies of human resource management. Unpublished PhD Dissertation. School of Business, The University of Notre Dame Australia, Broadway, NSW.

Latemore, G. 2020c. A tale of two leaders - Trump and Ardern. John Menadue - Pearls and Irritations. Posted on 20th April 2020. Retrieved on 2nd July 2020 from https://johnmenadue.com/?s=latemore

Letten, J., Reicher, S. D., Haslam, S. A., and Cruwys, T. 2020. Together Apart: The Psychology of COVID-19. Ebook. Retrieved on 1st June 2020 from https:/www.socialsciencespace.com/wp-content/uploads/TogetherApart-Complete-ms.pdf

MacIntyre, A. 2007. After virtue: A study in moral theory. 3rd ed. Notre Dame: The University of Notre Dame Press (Original work published 1981).

MacIntyre, A. 2016. Ethics in the conflicts of modernity: An essay on desire, practical reasoning, and narrative. Cambridge: Cambridge University Press.

Makhlouf, H. H. 2017. Globalization, trade, and interdependence, International Journal of Economics and Financial Research, Academic Research Publishing Group, 3(10), 202-205.

Maritain, J. 1960. Education at the Crossroads [The Terry lectures]. New Haven: Yale University Press (Original work published 1943).

Maritain, J. 1966. The person and the common good. Paperback ed. Notre Dame: University of Notre Dame Press (Original work published 1947). 
Maritain, J. 1996. Integral Humanism: Freedom in the Modern World and a Letter on Independence [The collected works of Jacques Maritain, volume 11], O. Bird, O. Bird, J. Evans (Eds.) \& R. O’Sullivan (Trans.). Notre Dame, IN: University of Notre Dame Press. (Original work published 1936).

Maritain, J. 1998. Man and the state. Washington, DC: The Catholic University of America Press (Original work published 1951).

McInerny, D.Q. 2007. The social thought of Jacques Maritain. The Catholic Social Science Review 12: 155-172.

Mea, W.J., and R.R. Sims. 2018. Human dignity-centred business ethics: A conceptual framework for business leaders. Journal of Business Ethics 160 (1): 53-69.

Melé, D. 2016. Understanding humanistic management. Humanistic Management Journal 1: 33-55.

Morral, A. R., and Travis, J. 2020. COVID-19 pandemic run on guns underscores the need for more research about gun safety. USA Today. 17th June 2020. Retrieved on 2nd July 2020 from https://www.usatoday. com/story/opinion/2020/06/17/coronavirus-record-gun-sales-show-need-for-research-column/3190486001/

Northouse, P.G. 2018. Leadership: Theory and practice. 8th ed. Thousand Oaks: Sage.

Notebaert, L. 2020. COVID-19: The psychology of panic buying. University News. Retrieved on 21st July 2020 from http://www.news.uwa.edu.au/2020042812028/uwa-public-policy-institute/covid-19-psychologypanic-buying?page=show

O'Brien, T. 2008. Reconsidering the common good in a business context. Journal of Business Ethics 85: 25-37.

Obioha, U.P. 2014a. A communitarian understanding of the human person as a philosophical basis for human development. The Journal of Pan African Studies 6 (8): 247-267.

Obioha, U.P. 2014b. Radical communitarian idea of the human person in African philosophical thought: A critique. The Western Journal of Black Studies 38 (1): 13-23.

Pambuccian, S.E. 2020. The COVID-19 pandemic: Implications for the cytology laboratory. Journal of the American Society of Cytopathology. https://doi.org/10.1016/j.jasc.2020.03.001.

PK. 2020. Pandemic Kindness Movement - Agency for clinical innovation, Retrieved on 20th July 2020 from https://aci.health.nsw.gov.au/covid-19/kindness

PSC [Public Service Commission, NSW]. 2020. Behaving ethically - 4.1 Acting in the public interest. Retrieved on 21 st July 2020 from https://www.psc.nsw.gov.au/employmentportal/ethics-conduct/behavingethically/behaving-ethically-guide/section-4/4-1-acting-in-the-public-interest

Rashdall, H. 2005. The Theory of Good and Evil: A Treatise on Moral Philosophy (part 1). Whitefish: Kessinger Publishing (Original work published 1907).

Rawls, J. 1999. A theory of justice. Revised ed. Cambridge: The Belknap Press of Harvard University Press (Original work published 1971).

Rittel, H. W. J., and Webber, M. M. 1973. Dilemmas in a general theory of planning. Policy Sciences, June, 4(2), $155-169$.

Rohlf, M. 2020. Immanuel Kant, The Stanford Encyclopedia of Philosophy (Spring 2020 ed. minor correction), Zalta, E. N. (Ed.). Retrieved on 21st July 2020 from https://plato.stanford.edu/archives/spr2020/entries/kant

Rost, J.C. 1991. Leadership for the twenty-first century. New York: Praeger.

Sandel, M.J. 2009. Justice: What is the right thing to do? London: Allen Lane - an imprint of Penguin Books Ltd..

Sandel, M. J. 2018. Democracy and the common good: what do we value? Public debate at St. Paul's Cathedral, 11th June 2018. Retrieved on 29th June 2020 from https://www.youtube.com/watch?v=foQXv99A9aw

Stevenson, A. 2020. How conspiracy theories undermine the common good. ABC Religion and Ethics Report. Retrieved on 23rd June 2020 from https:/www.abc.net.au/religion/how-conspiracy-theories-undermine-thecommon-good/12373294

Sweet, W. 2019. Jacques Maritain, Stanford encyclopedia of philosophy, [Summer 2019 edition], E. N. Zalta (Ed.). Retrieved on 24th may 2020 from https://plato.stanford.edu/archives/sum2019/entries/maritain

Tanguay-Renaud, F. 2009. Making sense of 'public' emergencies. Philosophy of Management 8: 31-53.

Thurman M. P. 1991. Strategic leadership. Presentation to the strategic leadership conference, US Army War College, Carlisle Barracks, PA, 11th February. Retrieved on 3rd July 2020 https://warroom.armywarcollege. edu/articles/moral-leadership/

United Nations, 1948. Universal Declaration of Human Rights. General Assembly Resolution 217A, Paris, 10th December. Retrieved on 4th July 2020 from the United Nations website https://www.un.org/en/universaldeclaration-human-rights

Vandekerckhove, W. 2020. COVID, existentialism and crisis philosophy. Philosophy of Management 19: 127-132.

Weimer, D.L., and A.R. Vining. 2017. Policy analysis: Concepts and practice. 6th ed. Abingdon: Routledge (Original work published 1989).

Wheeler, C. 2006. The public interest - We know it's important, but do we know what it means? AIAL [Australian Institute of Administrative Law] forum no. 48. Retrieved on 21st July 2020 from http://www5. austlii.edu.au/au/journals/AIAdminLawF/2006/2.pdf 
Wolf, M. 2020. How COVID-19 will change the world. Financial Times [Opinion]. 17th June 2020. Retrieved on 1st July 2020 https://www.ft.com/content/9b8223bb-c5e4-4c11-944d-94ff5d33a909

Woodard, C. 2016. American character: A history of the epic struggle between individual liberty and the common good. New York: Viking.

World Health Organization, WHO. 2020a. WHO Coronavirus Disease (COVID-19) Dashboard. Retrieved on 2nd July 2020 from https://covid19.who.int/

World Health Organization, WHO. 2020b. UN Office for Disaster Risk Reduction, Office in Incheon for Northeast Asia and Global Education and Training Institute for Disaster Risk Reduction (UNDRR ONEA \& GETI). Retrieved on 3rd July 2020 from http://www.undrr.org/incheon

Yukl, G., and W.L. Gardner III. 2020. Leadership in organizations. 8th ed. Harlow: Pearson Education Limited. Zack, N. 2009. The ethics of disaster planning: Preparation vs response. Philosophy of Management 8: 55-66. Zaleznik, A. 1977. Managers and leaders: Are they different? Harvard Business Review 55: 67-78.

Publisher's Note Springer Nature remains neutral with regard to jurisdictional claims in published maps and institutional affiliations.

Gregory Latemore completed his $\mathrm{PhD}$ at The University of Notre Dame Australia in 2020. He has been a management consultant since 1992 and lectured at three Australian Universities in Human Resource Management since 1998 . 